\title{
High Intensity Focused Ultrasound Technology, Its Scope and Applications in Therapy and Drug Delivery
}

\author{
Christopher P. Phenix ${ }^{1,2,3}$, Melissa Togtema ${ }^{1,4}$, Samuel Pichardo ${ }^{5,6}$, Ingeborg Zehbe ${ }^{1,3,4}$ and Laura Curiel $^{1,6}$ \\ ${ }^{1}$ Thunder Bay Regional Research Institute, Thunder Bay, Ontario, Canada; ${ }^{2}$ Department of Chemistry, Lakehead \\ University, Thunder Bay, Ontario, Canada; ${ }^{3}$ Medical Sciences Division, Northern Ontario School of Medicine, Sudbury \\ and Thunder Bay, Ontario, Canada; ${ }^{4}$ Department of Biology, Lakehead University, Thunder Bay, Ontario, Canada; \\ ${ }^{5}$ Imaging Research, Sunnybrook Health Sciences Centre, Toronto, Ontario, Canada; ${ }^{6}$ Department of Electrical Engineering, \\ Lakehead University, Thunder Bay, Ontario, Canada
}

Received, December 10, 2013; Revised, February 14, 2014; Accepted, March 12, 2014; Published, March 31, 2014

\begin{abstract}
Ultrasonography is a safe, inexpensive and wide-spread diagnostic tool capable of producing real-time non-invasive images without significant biological effects. However, the propagation of higher energy, intensity and frequency ultrasound waves through living tissues can induce thermal, mechanical and chemical effects useful for a variety of therapeutic applications. With the recent development of clinically approved High Intensity Focused Ultrasound (HIFU) systems, therapeutic ultrasound is now a medical reality. Indeed, HIFU has been used for the thermal ablation of pathological lesions; localized, minimally invasive ultrasoundmediated drug delivery through the transient formation of pores on cell membranes; the temporary disruption of skin and the blood brain barrier; the ultrasound induced break-down of blood clots; and the targeted release of drugs using ultrasound and temperature sensitive drug carriers. This review seeks to engage the pharmaceutical research community by providing an overview on the biological effects of ultrasound as well as highlighting important therapeutic applications, current deficiencies and future directions.
\end{abstract}

This article is open to POST-PUBLICATION REVIEW. Registered readers (see "For Readers") may comment by clicking on ABSTRACT on the issue's contents page.

\section{INTRODUCTION}

In 1880, the Curie brothers reported that certain crystalline materials generated an electric potential when subjected to mechanical pressure (1), a phenomenon later named the piezoelectric effect. Practical applications of piezoelectric properties enabled the development of transducers which could generate ultrasound waves for different uses, of which submarine sonar was one of the earliest (2). Since then, ultrasound has been used in every day devices such as alarms, vaporizers, medical imaging and important industrial processes like plastic welding, material cleaning, and nondestructive testing.

In the pharmaceutical and chemical industries, the application of ultrasound to promote chemical processes is broadly known as sonochemistry (3). Sonochemistry, or the physical and chemical interaction of ultrasound with molecular species, has been thoroughly studied (35 ) and is an important tool for promoting reactions used for synthetic and medicinal chemistry as well as for improving drug extraction processes (6-9). Ultrasound is being explored to solve pharmaceutical manufacturing and formulation issues (10) as well as the dispersion of solids, the deagglomeration of solids in liquid and the preparation of colloids. In addition, ultrasound has been used in the development of novel catalysts, nanomaterials, nanocrystals and nanoscale catalysts among other applications (11-13).

Diagnostic imaging is the most widespread medical application of ultrasound used as a clinical tool for more than 40 years, mainly due to its nonionizing nature and the ability to conduct real-time imaging (14). In addition, ultrasound energy is used clinically for thermal tissue ablation, haemostasis, thrombolysis and to promote tissue regeneration (15-17). More recent developments have focused on

Correspondence Author: Christopher Phenix, Thunder Bay Regional Research Institute, 2321-290 Munro Street, Thunder Bay, ON, Canada, P7A 7T1; Email: phenixc@tbh.net. 
the use of ultrasound for molecular imaging (18), as well as ultrasound-mediated therapeutic biomolecule and drug-delivery $(15,19,20)$. This has highlighted the value of developing applications with contributions from physicists, medicinal chemists, biologists, material and pharmaceutical scientists. In this article, we intend to draw attention to the potential uses of high intensity ultrasound for therapeutic purposes and the need for multidisciplinary efforts required for expanding its clinical application.

\section{ULTRASOUND BIOLOGICAL EFFECTS}

Initial reports on the biological effects of ultrasound appeared as early as 1928 when changes in living tissues caused by exposure to high intensity and frequency sound waves were reported (21). During the 1940s, the use of focused ultrasound for therapeutic ablation, or ultrasonic surgery, was first proposed (22) and was later used to treat patients with Parkinson's disease and other neurological conditions (23). Nevertheless, the therapeutic applications of ultrasound were held back by the lack of imaging guidance during the treatment process raising important safety issues. With the development of ultrasound imaging, the potential hazardous effects of ultrasound were thoroughly investigated and damage mechanisms, thresholds, and propagation properties through tissues were elucidated (24-28). The term ultrasonic dosimetry, which relates ultrasound intensity, acoustic pressure and other physical parameters with the likelihood of producing biological alteration, was created to guide the design of ultrasound imaging devices. Fortuitously, ultrasound dosimetry studies intended for assessing the safety of diagnostic imaging have advanced our understanding of the effects of ultrasound on cells and tissues inspiring the development of more advanced therapeutic applications $(26,29)$. Two main biological effects are observed when high intensity acoustic waves propagate through tissues: thermal and mechanical.

\section{Thermal Effects}

When ultrasound waves propagate through tissues the wave amplitude decreases with distance. This phenomenon is called attenuation and is due to wave absorption and scattering (26). Absorption is the mechanism whereby a portion of the wave energy is converted into heat while scattering results from the wave changing direction. As a result of acoustic absorption, tissue temperature increases at a rate greater than heat dissipation caused by conduction or blood perfusion. Tissue temperature increases caused by ultrasound energy can be calculated through the widely used bio-heat transfer equation (BHTE) (30). It is then possible to estimate the thermal dose (31) and evaluate if the dose is high enough to reach the threshold values at which tissue damage in the form of coagulation necrosis will appear (32-34).

By using these calculations, researchers can predict the tissue response to the thermal effects of ultrasound and therefore exert control by changing the exposure parameters such as time, power, frequency, geometry or distance. These techniques have been successfully used for a variety of ultrasound exposure conditions and tissue types for the design and planning of thermal treatments on bone $(35,36)$, prostate $(37)$, heart $(38-40)$ and brain (36).

\section{Mechanical Effects}

The mechanical effects induced by high intensity ultrasound include cavitation, microstreaming and radiation force. The phenomenon of acoustic cavitation begins when gas filled cavities, called microbubbles, which spontaneously form or are naturally present in a liquid medium oscillate under the influence of an acoustic wave. The term cavitation was first proposed as an explanation for rapid erosion on ship propellers caused from enormous turbulence, heat and pressure produced by bubbles in the water (41).

There are two forms of acoustic cavitation, inertial and non-inertial. Non-inertial cavitation is described as the stable oscillation of gas-filled bodies in an ultrasonic field whereas inertial cavitation results when a gas-filled cavity expands during part of the acoustic cycle and then collapses rapidly because of erratic oscillations and rapid growth of the cavity. This violent collapse produces high temperatures and pressures with important practical consequences such as light emission and the formation of reactive chemical species. In contrast, non-inertial cavitation causes bubble oscillation and solution microstreaming producing shear forces in the microenvironment. Bubble oscillation also produces mechanical effects caused by the viscous surrounding fluid which opposes the oscillation, creating what is known as radiation 
force (42).

The complexity of the cavitation phenomenon depends precisely on the type of the media exposed to ultrasound, making it difficult to obtain a consistent response from living tissues which vary in composition. Even though multiple mathematical models have been proposed to predict and exploit cavitation generated by ultrasound, there is not a single widespread mathematical model currently used for predicting the mechanical bioeffects (43). Nevertheless, important models have been developed to allow for more controlled parameter choice and treatment planning for therapeutic applications that consider mechanical bioeffects (44-46).

\section{ULTRASOUND IN THERAPY: HIGH INTENSITY FOCUSED ULTRASOUND}

High intensity focused ultrasound, widely known as HIFU, was born out of the medical application of the thermal effects of ultrasound waves. Whereas the maximum allowed time-averaged intensities of diagnostic ultrasound are $0.72 \mathrm{~W} / \mathrm{cm}^{2}$ (47), HIFU has intensities in the range of 100 to $10,000 \mathrm{~W} / \mathrm{cm}^{2}$ $(15,48)$. The ultrasound wave is brought into a tight focus usually $1 \mathrm{~mm}$ in diameter and $10 \mathrm{~mm}$ in depth such that the thermal effects are localized. The temperature increases at the focus to more than $60^{\circ} \mathrm{C}$ for several seconds causing irreversible cell death via coagulation necrosis, without damaging the surrounding tissues where the energy density is significantly lower. The ability of HIFU to focus high intensity waves makes it an attractive noninvasive treatment option for ultrasound surgery (15). The optimal choice of ultrasound parameters is application-specific and represents a compromise between the target depth and the desired rate of heating. For superficial therapies such as intraurethral prostate treatment the frequencies can be as high as $8 \mathrm{MHz}$, whereas frequencies as low as 500 $\mathrm{kHz}$ are used for deep tissue treatments or treatments through the skull (29).

As mentioned above, the first medical application of HIFU was proposed as an extracorporeal neurosurgery device (49). In the early 1980s, HIFU was used to treat glaucoma and intraocular tumours (50) but was eventually replaced by laser technology. However, there is renewed interest in HIFU for ophthalmological applications due to better focusing capabilities (48).
By the mid 1980s, multiple groups were engaged in HIFU for treating tumours either by inducing localized hyperthermia or tissue ablation leading to multiple clinical trials and the development of commercial devices in the 1990s. Recently, the number of clinical applications of therapeutic HIFU has expanded to include treatment of uterine fibroids (51), glaucoma (48), prostate (52-56), breast $(57,58)$, heart $(39,40,59)$, pancreas $(60)$, liver and esophageal tumours $(61,62)$. HIFU has also been proposed for thrombolysis (63), hemostasis $(64,65)$ and the treatment of venous insufficiency (66).

Studies evaluating the pathological changes in normal and malignant human tissues following exposure to HIFU have shown that thermally ablated tissues undergo homogeneous coagulative necrosis with irreversible tumour cell death and severe damage to tumour blood vessels at the microvasculature level (67). In breast cancer patients, it was confirmed that HIFU-ablated tumour cells did not continue to express cerbB-2 protein, estrogen and progesterone receptors, when compared to non-ablated tumour tissues $(57,68)$. HIFU has also been found to elicit acute inflammatory responses increasing tumour tissue destruction through immune cell activation, which could enhance the treatment response by acting synergistically with other therapies (69-71).

Three main categories of HIFU devices are currently used in the clinical setting and are usually classified according to the ultrasound energy delivery path: extracorporeal, intracavitary or interstitial. Extracorporeal devices are used for targeting organs that are readily accessible through an acoustic window on the skin such as uterine fibroids or breast $(51,58)$; intracavitary devices are used for transrectal and transurethral treatment of prostate cancer $(52,72)$ or for intraesophageal treatment $(38,62)$; and interstitial devices are used for treating the biliary duct and other difficult to access targets $(73,74)$.

Commercial HIFU devices have been in the market since 1995, when Ablatherm ${ }^{\circledR}$ (EDAP Technomed S.A., Vaulx-en-Velin, France) $(72,75)$ and Sonablate 500 (Focus Surgery Inc., Indianapolis, USA) $(55,56)$ started clinical treatment of the prostate. In October 2004, the FDA approved a HIFU device for the treatment of uterine fibroids, ExAblate (Insightec, Haifa, Israel) (76), which uses magnetic resonance imaging (MRI) for 
treatment guidance, targeting and monitoring. Recently, the FDA classified HIFU systems as Class II (special controls) devices, in order to provide a reasonable assurance of safety and effectiveness of the equipment (77). Advanced devices such as Sonalleve (Phillips, The Netherlands) and ExAblate 2100 (Insightec, Haifa, Israel) are currently approved for clinical use on uterine fibroids and for relief of pain from bone metastases.

\section{HIFU FOR NON-INVASIVE DRUG DELIVERY}

Enhanced response to therapeutic agents after ultrasound exposure has sparked interest in HIFU as a drug delivery tool (15). Acoustic cavitation and the associated microstreaming effects from confined and localized forces are believed to be the mechanisms responsible for ultrasound-mediated drug delivery. While the physical mechanisms behind the enhanced delivery are similar, applications have been divided according to their therapeutic goal. We will describe each delivery application commonly associated with HIFU devices as they are either performed at high energy levels attainable only by HIFU or they are combined with an ablation therapy using HIFU.

\section{Sonophoresis}

Transdermal enhanced delivery of drugs using ultrasound was first reported in 1954 when hydrocortisone was used to treat polyarthritis in conjunction with ultrasound. This delivery method is known as sonophoresis and is currently used as a powerful tool to enhance transdermal drug delivery and achieve needle-free drug administration (78). For a detailed review on the mechanisms of action, current uses and trends in the field of transdermal sonophoresis see Escobar-Chavez et al. (79).

The technique works by the shock waves generated from collapsing cavitating bubbles found naturally in the skin, that introduce small openings in the intracellular spaces allowing for the passage of small molecules (80). Since cavitation is more common at lower frequencies, sonophoresis is performed by devices that work under $100 \mathrm{kHz}$ (78). As HIFU is usually performed at higher frequencies and depths, it is typically not associated with sonophoresis. However, the energy levels required for sonophoresis as well as the reported bioeffects are compatible with HIFU devices. The delivery facilitated by sonophoresis induces dispersion of the drug throughout the epithelial layers, but has not yet been proven to enhance intracellular delivery (79).

\section{Sonoporation}

The transient permeabilization of cell membranes through ultrasound-induced pores in the lipid bilayer is known as sonoporation. Inertial cavitation induced by ultrasound at an interface, such as the membrane of a cell or tissue barrier, causes microbubbles within the focal point to collapse in a non-spherical manner driving high-speed jets of liquid into the interface (Figure 1). These jets are believed to produce temporary pores in the cell membrane as well as cause microstreaming in the extracellular environment. The passage of therapeutic agents occurs through the pores propelled in part by the mechanical effects of the microstreaming (81-83) (Figure 2) with additional effects from ultrasound induced endocytosis (84). Cavitation can be achieved through the natural formation of microbubbles under the influence of the high intensity ultrasound waves or it can be potentiated and controlled by exogenous systemic administration of microbubbles.

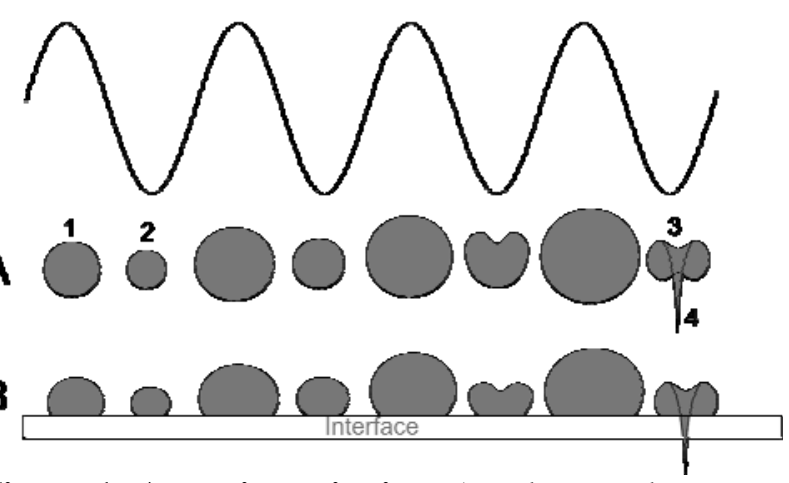

Figure 1. Acoustic cavitation. An ultrasound wave generates changes in pressure in the propagation medium where microbubbles are present. The microbubbles can be floating in the medium (A) or pushed against an interface (B) by the radiation force. When an inertial cavitation regime is present the microbubbles expand (1) and contract (2) in response to the pressure changes and eventually implode (3) leading to the generation of liquid streaming or jetting (4). The force generated by a high pressure jet of surrounding liquid may be sufficient enough to dent a solid surface or introduce pores in a nearby cellular membrane. 


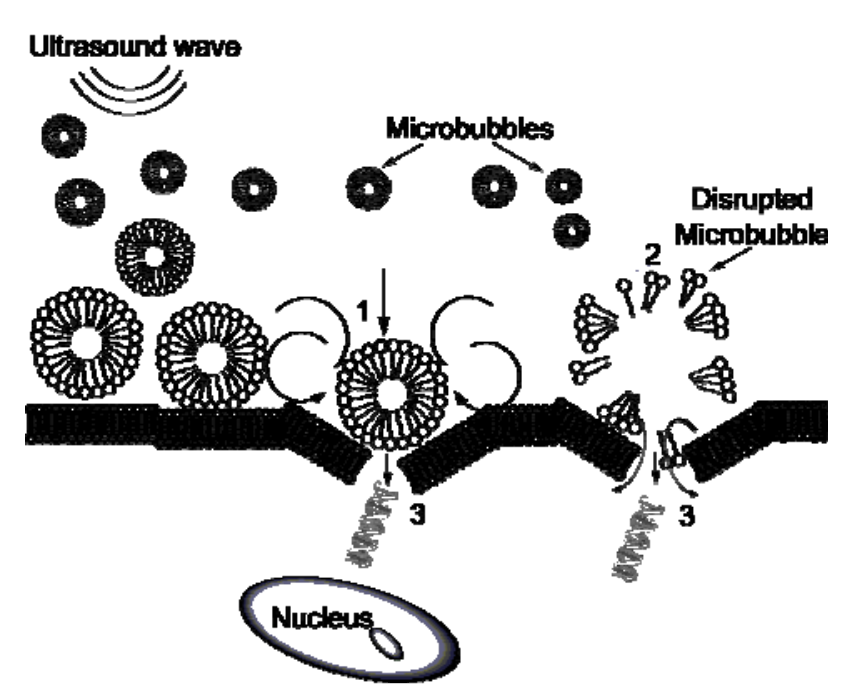

Figure 2. Sonoporation mechanism. The ultrasoundirradiated gas-filled microbubbles resonate under the influence of the pressure change and are pushed by the radiation force toward the cell membrane. Transient pores appear when the cell membrane is disrupted by the expansion of the bubbles (1) or bubble collapse (2). The collapse and expansion of the microbubbles generate shear forces around the cell membrane that cause microstreaming, propelling the agents through the temporarily formed pores.

Microbubbles typically used for sonoporation are clinically approved diagnostic ultrasound contrast agents $(85,86)$ and are currently available in the form of either microcrystalline or microbubble emulsions. Table 1 highlights the nature and application of currently available ultrasound contrast agents used for sonoporation. Ultrasound has been successfully used in preclinical studies to introduce membrane impermeable agents into cells or tissues $(87,88)$ including small interfering ribonucleic acid (siRNA) (89,90), peptides (91,92), plasmid DNA (93-95), nanoparticles $(88)$ and antibodies $(87,96)$ (see Table 2 for a summary). The application of sonoporation for the treatment of cancer (87,91,96-98), cardiovascular disease $(99,100)$ and for gene therapy (101) is currently being explored.

In addition to the therapeutic effect caused by enhanced drug delivery into the cells, sonoporation has been suggested to enhance the cytotoxicity of anticancer therapeutic molecules $(102,103)$ and promote ultrasound-induced apoptosis $(92,104,105)$. Ultrasound-induced apoptosis is observed as a delayed biological effect in tissues exposed to high intensity ultrasound, especially in cell types that regenerate poorly such as neurons. Glioma cells exposed to ultrasound were shown to have increased caspase- 3 expression and decreased expression of anti-apoptosis factors such as Bcl-2 and survivin leading to ultrasound induced cell death (106).

Efforts to improve sonoporation-based therapies or the diagnostic specificity of ultrasound have led to the development of chemically modified microbubbles that possess either receptor targeting ligands or carry a drug payload (Figure 3).

Advanced microbubbles that target a specific cell receptor have been successfully developed for ultrasound imaging and include microbubbles that bind to the P-selectin of activated platelets for atherosclerotic plaque detection $(107,108)$, lipopeptides incorporated into the bubble membrane to target vascular endothelial growth factor (VEGF)
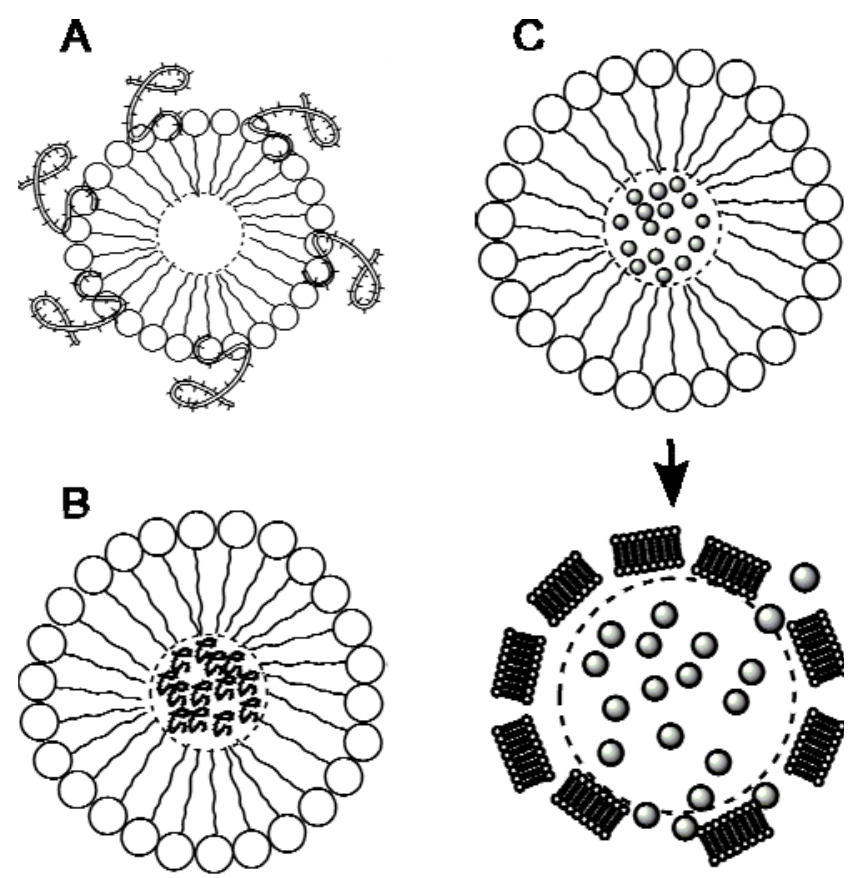

Figure 3. Microbubbles as delivery agents. Gasfilled microbubbles can be used as delivery agents by incorporating ligands on the hydrophobic ends (A), encapsulating ligands within the microbubble that would be delivered upon bubble collapse (B), or encapsulating drugs or nanoparticles within the microbubble which would be delivered when the bubble collapses (C). These microbubbles can act as carriers of drugs, gene therapy, small interfering RNA (siRNA) or other nanoparticles. 
Table 1. Proprietary agents used for contrast enhanced ultrasound (CEUS), compositions, indications and current market status

\begin{tabular}{|c|c|c|c|c|}
\hline $\begin{array}{l}\text { Contrast } \\
\text { agent }\end{array}$ & Composition & $\begin{array}{l}\text { Imaging } \\
\text { Indications }\end{array}$ & $\begin{array}{l}\text { Sonoporation } \\
\text { application }\end{array}$ & Market status \\
\hline Albunex & $\begin{array}{l}\text { Air filled albumin microspheres } \\
\text { suspended in } 5 \% \mathrm{w} / \mathrm{v} \text { human } \\
\text { serum albumin }\end{array}$ & Echocardiography & $(93,184)$ & $\begin{array}{l}\text { Developed by Molecular } \\
\text { Biosystems Inc } \\
\text { Marketed by Mallinckrodt } \\
\text { Inc. }\end{array}$ \\
\hline $\begin{array}{l}\text { Definity } \\
\text { (formerly } \\
\text { Aerosomes) }\end{array}$ & $\begin{array}{l}\text { Perflutren (octafluoropropane } \\
\text { gas) lipid microspheres }\end{array}$ & Echocardiography & $(96,112)$ & $\begin{array}{l}\text { Developed by ImaRx } \\
\text { Therapeutics Inc } \\
\text { Marketed by Lantheus } \\
\text { Medical Imaging Inc }\end{array}$ \\
\hline Echovist-200 & $\begin{array}{l}\text { Microcrystalline suspension of } \\
\text { galactose }\end{array}$ & $\begin{array}{l}\text { Female genital } \\
\text { tract } \\
\text { Echocardiography }\end{array}$ & See Levovist ${ }^{\circledR}$ & $\begin{array}{l}\text { Developed by Schering AG } \\
\text { New formulation currently } \\
\text { marketed as Levovist }{ }^{\circledR}\end{array}$ \\
\hline Levovist & $\begin{array}{l}\text { Microcrystalline suspension of } \\
\text { galactose and palmitic acid in } \\
\text { sterile water }\end{array}$ & $\begin{array}{l}\text { Female genital } \\
\text { tract } \\
\text { Echocardiography }\end{array}$ & (184) & $\begin{array}{l}\text { Developed by Schering AG } \\
\text { Marketed by Bayer } \\
\text { Schering Pharma AG }\end{array}$ \\
\hline Optison & $\begin{array}{l}\text { Perflutren protein-type A } \\
\text { microspheres (human serum } \\
\text { albumin) and perflutren } \\
\text { (octafluoropropane gas) }\end{array}$ & Echocardiography & $(91,184)$ & $\begin{array}{l}\text { Developed by Molecular } \\
\text { Biosystems Inc } \\
\text { Marketed by Nycomed } \\
\text { Amersham and } \\
\text { Mallinckrodt, now GE } \\
\text { Healthcare Inc }\end{array}$ \\
\hline Sonovue & $\begin{array}{l}\text { Phospholipid stabilized sulphur } \\
\text { hexafluoride microbubbles }\end{array}$ & Echocardiography & (84) & $\begin{array}{l}\text { Developed and marketed } \\
\text { by Bracco Imaging }\end{array}$ \\
\hline
\end{tabular}

and image angiogenesis (109), as well as antibodyloaded microbubbles to detect prostate cancer by targeting the prostate-specific membrane antigen (PSMA) (110). Since gas microbubbles are typically prepared by high-shear mixing of the gas in liquid phase with the shell-forming material, stable targeting vectors such as peptides, some proteins, oligosaccharides and other small molecules can be attached to the shell forming component prior to the bubble formation. A modified procedure is important when incorporating proteins such as antibodies and enzymes, both of which can be unstable at high temperature and under the sonication conditions required for bubble formation. For such targeted microbubbles, a modified anchor amenable to protein attachment is incorporated into the shell forming agent and included during the formulation process. Conjugation of the protein to the preformed microbubble bearing the appropriate anchor can then proceed under mild conditions (111).

Sonoporation is an attractive tool for molecule delivery that can be applied noninvasively and in a localized manner by focusing the ultrasonic energy to a specific area. Enhanced drug uptake has been shown to be localized, and multiple studies have indicated that large and small molecules can be successfully delivered (112). Others have optimized the ultrasound parameters and physical settings that achieve the best results $(90,113)$, including the temporal window for successful delivery (114) and the biological conditions that can influence response (95). Sonoporation would benefit greatly from advanced targeted-microbubble formulations for therapy and the production of custom-developed microbubbles specific to a therapeutic target or an intended application.

\section{Blood Brain Barrier Disruption}

Other uses of ultrasound cavitation have been explored such as the treatment of gliomas through locally induced transient disruption of the blood brain barrier (BBB) produced by employing a combination of high intensity ultrasound, doxorubicin and Optison ${ }^{\circledR}$ microbubbles (115). Like sonoporation, cavitation is also believed to be the main mechanism behind the reversible opening of the BBB improving drug uptake in the brain. 
Table 2. Application of microbubbles in sonoporation

\begin{tabular}{|c|c|c|c|c|}
\hline $\begin{array}{l}\text { Microbubbles } \\
\text { used }\end{array}$ & Cells used & Molecules transfected into cells & $\begin{array}{c}\text { Parameters } \\
\text { tested }\end{array}$ & Reference \\
\hline Albunex & Chinese Hamster Ovarian Cells & Luciferase plasmid, FITC-dextran & $\begin{array}{l}\text { Gene and } \\
\text { macromolecule } \\
\text { delivery }\end{array}$ & (93) \\
\hline Optison & $\begin{array}{l}\text { HeLa and Epstein Barr Virus } \\
\text { positive BJAB cells }\end{array}$ & Calcein, Bak BH3 peptide & Peptide delivery & (91) \\
\hline Optison & $\begin{array}{l}\text { Epstein Barr virus positive } \\
\text { BJAB , SV-40 and HSV } \\
\text { containing mouse C166 and } \\
\text { C166-GFP cells }\end{array}$ & Calcein, eGFP siRNA, pEGF-C3 & siRNA delivery & (89) \\
\hline $\begin{array}{l}\text { Soft (1A009) } \\
\text { and hard } \\
\text { (BG1766) } \\
\text { shelled } \\
\text { ultrasound } \\
\text { contrast agents }\end{array}$ & $\begin{array}{l}\text { Rat mammary adenocarcinoma } \\
\text { MAT B III cells }\end{array}$ & $\begin{array}{l}\text { FITC dextran, fluorescent latex } \\
\text { nanospheres }[25,44,75 \mathrm{~nm} \text { sizes }]\end{array}$ & $\begin{array}{l}\text { Nanoparticle } \\
\text { delivery }\end{array}$ & (88) \\
\hline Optison & $\begin{array}{l}\text { Jurkat lymphocytes, human } \\
\text { peripheral blood mononuclear } \\
\text { cells }\end{array}$ & $\begin{array}{l}\text { Anti-rabbit IgG-Alex Fluor }{ }^{\circledR} \text {, anti- } \\
\text { mouse IgD-FITC, Adriamycin } \\
\text { hywdrochloride }\end{array}$ & $\begin{array}{l}\text { Antibody and } \\
\text { Drug delivery }\end{array}$ & (87) \\
\hline Optison & $\begin{array}{l}\text { SV-40 and HSV containing } \\
\text { C166 cells, C166-GFP cells }\end{array}$ & Calcein, eGFP siRNA & siRNA delivery & (90) \\
\hline Optison & Chinese Hamster Ovarian cells & FITC-dextran & $\begin{array}{l}\text { Macromolecule } \\
\text { delivery }\end{array}$ & (185) \\
\hline Sonovue & $\begin{array}{l}\text { Primary bovine aortic } \\
\text { endothelial cells, rat femoral } \\
\text { arteries }\end{array}$ & $\begin{array}{l}\text { Tetramethylrhodamine, } \\
\text { isothiocynate-dextran, FITC } \\
\text { dextran, lysine fixable FITC } \\
\text { dextran }\end{array}$ & $\begin{array}{l}\text { Drug and } \\
\text { macromolecule } \\
\text { delivery }\end{array}$ & (84) \\
\hline $\begin{array}{l}\text { Optison } \\
\text { Definity }\end{array}$ & Rat KHT-C fibrosarcoma cells & FITC-dextran & $\begin{array}{l}\text { Macromolecule } \\
\text { delivery }\end{array}$ & (112) \\
\hline Sonovue & Rat glial C6 cells & $\begin{array}{l}\text { Sytox Green, Sytox Blue, TOTO-3 } \\
\text { intercalating fluorophores }\end{array}$ & $\begin{array}{l}\text { Macromolecule } \\
\text { delivery }\end{array}$ & (114) \\
\hline Sonovue & Human MCF-7 cells & $\begin{array}{l}\text { Polyethylenimine:deoxyribonucleic } \\
\text { acid }\end{array}$ & DNA delivery & (94) \\
\hline Sonovue & HEK-293T cells & $\begin{array}{l}\text { Branched Polyethylenimine, } \\
\text { Vascular endothelial growth factor } \\
\text { (165) peptide }\end{array}$ & Peptide delivery & (92) \\
\hline Definity & $\begin{array}{l}\text { HPV-positive CaSki and SiHa } \\
\text { cells }\end{array}$ & $\begin{array}{l}\text { Monoclonal anti-E6 oncoprotein } \\
\text { (F127-6G6) antibody from Arbor } \\
\text { Vita and monoclonal anti-tubulin } \\
\text { antibody }\end{array}$ & $\begin{array}{l}\text { Antibody } \\
\text { delivery }\end{array}$ & (96) \\
\hline $\begin{array}{l}\text { Cationic } \\
\text { liposomes and } \\
\text { Sonovue }\end{array}$ & Rat carotid artery & $\begin{array}{l}\text { Full-length cDNAs of rabbit } \\
\text { Scavenger receptor class B } \\
\text { member } 1 \text { (SR-BI) }\end{array}$ & $\begin{array}{l}\text { SR-BI DNA } \\
\text { expression }\end{array}$ & (186) \\
\hline
\end{tabular}

Initial work revealed that short, high-intensity ultrasound waves above the cavitation threshold were found to produce temporary BBB disruption. Unfortunately, the therapeutic benefit was hindered by brain tissue damage occurring in some animals (116). This was resolved when BBB disruption was consistently produced using focused ultrasound with concomitant injection of intravascular gas microbubbles as additional cavitation sites. Moreover, the use of microbubbles reduced the required ultrasound intensity to levels below the threshold causing thermal damage to adjacent brain tissue and was more compatible with the induction of focal points within the skull (117).

The physical mechanism for BBB disruption is attributed to microbubbles cavitation activity but 
the bioeffects are different compared to sonoporation. When the microbubbles pass through the tissue volume exposed to ultrasound they expand and contract at the frequency of the propagating acoustic wave due to the cyclic pressure reductions producing mechanical forces and microstreaming. In addition, the bubbles are pushed by a radiation force that moves them towards the vessel wall. Above an intensity threshold, the bubbles collapse close to the vessel wall creating fluid jets that can puncture the BBB allowing the passage of molecules through the barrier (116). Studies on the cellular mechanisms of this disruption have shown that macromolecule permeability is caused by the mechanical forces inducing the formation of channels and fenestrations in the endothelial cell wall, the opening or widening of interendothelial clefts and free passage through injured endothelial lining when the pressure is sufficiently high (118).

When using microbubbles in combination with ultrasound, the disruption of the BBB has been proven to be reversible with minimal damage to the local surrounding tissues in animals $(20,117,119)$. Magnetic resonance imaging revealed that the BBB appears to remain permeable up to 24 hours after ultrasound exposure with optimal brain uptake occurring within 6 hours (117). Investigations into the safety of BBB disruption demonstrated that permeability is induced at $690 \mathrm{kHz}$ and pressure values of $0.4 \mathrm{MPa}$ significantly below the $2.3 \mathrm{MPa}$ required for tissue necrosis (120). Histological examination of adjacent tissues after BBB disruption demonstrated insignificant levels of apoptosis or ischemia, with no observable differences up to 4 weeks after the disruption (121).

Ultrasound-mediated BBB disruption has been validated on various animal models such as rabbits (117), rats (115), mice (122) and non-human primates (123). HIFU successfully delivered dopamine receptor antibodies (122), enhanced response of brain cancers to doxorubicin and trastuzumab $(115,124,125)$, promoted uptake of therapeutic antibodies for Alzheimer's treatment (126) and DNA for gene therapy (127). New formulations for microbubbles that target the BBB may greatly increase barrier permeability and have enormous potential for improving the introduction of proteins and other impermeable therapeutic agents into the brain.

\section{Sonothrombolysis}

The use of ultrasound to potentiate the breakdown of blood clots, known as sonothrombolysis, has been investigated for several decades. This technique was initially used for enhancing intravascular thrombus dissolution but, more recently, has also been proposed for treatment of stroke (128). Early reports described the use of lowfrequency ultrasound through the temporal bone to enhance thrombolysis in vitro (129). An improved efficacy of thrombolytic agents has been observed when coupled with ultrasound exposure, as reported by multiple groups (15). The mechanism for the enhanced thrombolytic effect of ultrasound was proposed to be the cavitation and collapse of endogenous microbubbles that disrupt the fibrin network (129). Further improvements were observed when thrombolytic agents were used in combination with ultrasound contrast agents, supporting the proposed disruption of fibrin by cavitation $(130,131)$. The mechanical lysis of the clot can potentiate the activity of thrombolytic agents by improving drug penetration and altering the accessibility of fibrin structures to clotdissolving enzymes $(131,132)$.

Sonothrombolysis is therefore usually performed in conjunction with thrombolytic agents, resulting in significant clinical improvements in clot lysis over the use of these agents alone (132). The advantage of using sonothrombolysis results from reduction in dose of thrombolytic agent required therefore reducing the risk of associated hemorrhage, hypotension and myocardial rupture (133). The procedure is frequently performed with commercial diagnostic devices capable of emitting higher ultrasound intensities, such as those used for Doppler imaging. Recent work on sonothrombolysis is centered on the development of specific devices that can provide more controlled and reproducible results without the need for specialized care teams or training (134). Having sonothrombolysis devices widely available in emergency centers is critical because of the need to maintain early and constant ultrasound exposure for improved clinical outcomes (132).

Currently, sonothrombolysis is also being explored as a standalone technique without the need for thrombolytic agents. Recent reports indicate that the use of ultrasound contrast agents are safe for sonothrombolysis and potentiate the therapeutic effect $(130,131)$. It is therefore conceivable to use 
only mechanical effects produced by ultrasound to induce clot lysis. In this context, HIFU may be the ideal approach that can provide the higher level of ultrasound energy required. Indeed, HIFU was successfully used to treat unconstrained clots in vitro (135) as well as constrained clots in vitro and in vivo (63). This work suggests that clot degradation is achieved by cavitation and can be monitored by changes in brightness of ultrasound images during treatment. New developments in biotechnology could advance sonothrombolysis therapy either by targeted thrombolytic agents $(136,137)$, or by employing a combination of targeted thrombolytic agents with microbubbles to enhance the ultrasound effects.

\section{Hyperthermia-triggered Drug Delivery}

The delivery or release of a drug at the desired site of action induced by the thermal effects of HIFU is known as hyperthermia-triggered drug delivery. The main purpose of this technique is to increase the therapeutic index of chemotherapeutics, which are often compromised by the distribution of the cytotoxic agent into normal organs and tissues leading to severe side effects. Additional benefits derive from enhanced serum stability and overcoming solubility issues compared to systemic administration of the parent drug.

Efforts to improve drug toxicity profiles while simultaneously protecting the drug from rapid metabolism and excretion has led to the development of temperature sensitive liposomes (TSL) (for a thorough review of TSL's see (138)). TSL encapsulate a water soluble drug within a hydrophilic core surrounded by a protective lipid bilayer (139). Injection of the nanosized liposome drug carrier into the patient results in the passive accumulation of the TSL into tumours through the enhanced retention and permeability effect. Site specific drug delivery is then fulfilled by mild hyperthermia causing the rapid and complete release of the drug into the tumour region. Mild hyperthermia of the tumour area and local vasculature is typically induced by microwave, radio or ultrasound waves (140). Although the spontaneous accumulation of drug containing liposomes typically occurs in tumour xenografts, mild local hyperthermia significantly enhances drug delivery into cancer cells and improves the therapeutic response $(141,142)$. Additional benefits from local hyperthermia result from enhancing the accumulation of the TSL in tumour tissue (143). In addition, increased blood flow to the tumour area coupled with enhanced cell permeability from hyperthermia induces improved delivery into cells of the tumour. However, it is important to acknowledge that hyperthermic drug release from the TSL in the tumour region is the dominant driving force leading to higher cellular uptake and improved therapeutic response (144). The success of the preclinical studies has led to a series of clinical trials evaluating a doxorubicin-loaded TSL called ThermoDox ${ }^{\circledR}$ (Celsion) for treatment of hepatocellular carcinoma (Phase III) and invasive breast cancer (Phase I) using microwave radiation to induce hyperthermia. Unfortunately, ThermoDox recently failed the phase III trial due to lack of patient benefit compared to the control group while the Phase I breast cancer study is still underway.

The application of HIFU to induce mild heating deep inside of tissues has considerable potential to improve the precision and clinical application of TSL-based chemotherapies. A significant benefit of HIFU hyperthermia results from the ability to focus and control heating by careful choice of the acoustic parameters including continuous or pulsed wave energy, frequency and intensity. Another significant advantage of using HIFU for hyperthermic drug delivery is its compatibility with MRI which enables real time thermometry monitoring of tissue temperature. Instantaneous feedback on the focal point coupled with accurate tissue temperature measurement through image guidance establishes HIFU as the most attractive device for hyperthermic drug delivery. Indeed, recent efforts to use MR guided HIFU to deliver ThermoDox was examined in rabbit muscle demonstrating increased Dox uptake in the area of hyperthermia (145). ThermoDox with HIFU was assessed as a complimentary therapy to thermal ablation of bone cancer with improved results (146). MR guided HIFU was used to treat rabbits bearing VX2 tumours with ThermoDox successfully sparing adjacent tissues from Dox uptake (147).

The application of molecular imaging to visualize and quantify HIFU-induced TSL drug release has recently gained attention. For example, TSL co-encapsulated with a Gadolinium contrast agent and Doxorubicin enabled imaging of TSL content release as demonstrated in vitro using squamous carcinoma cells (148) and later in a 
tumour $(149,150)$. This strategy was expanded to include the nuclear based SPECT imaging by Indium-111 radiolabeling of the TSLs coencapsulated with Gadolinium and Dox enabling the researchers to determine blood kinetics and clearance of the TSLs as well as to monitor TSL content release (151).

In order to translate HIFU into a routine drug delivery method used in the cancer clinic, several improvements are needed. Advanced heating algorithms for HIFU hyperthermia were investigated using a combination of mathematical modeling and in vivo experiments (152). Other groups have compared continuous wave versus pulsed wave HIFU in an effort to understand the mechanisms with which hydrophilic and lipophilic drugs are released from TSL (153). In addition, HIFU is an excellent preclinical tool to investigate the suitability of new formulations and compositions of TSL as well to evaluate new ultrasound sensitive drug carrier nanoparticles. For example, advanced nanosized "stealth" TSLs modified with the PEG polymer had high Doxorubicin loading capacity, enhanced physiological stability in circulation, faster drug release upon mild HIFU heating and improved efficacy compared to the traditional lysolipid TSL (154). Others have recently synthesized a novel TSL by using cholesterol and an elastin-like polypeptide as additives to produce liposomes having high serum stability and enhanced efficacy in tumour xenografts (155). Recent efforts have been made to expand the use of nanoparticles for encapsulating hydrophobic drugs using ultrasound sensitive micelles composed of hydrophobic polymers $(156,157)$.

\section{HIFU IMAGING GUIDANCE TRENDS}

Even though the therapeutic applications of ultrasound predated ultrasound imaging, it is the latter application which is universally known. The slow adoption of therapeutic ultrasound resulted from the lack of non-invasive targeting and temperature measurements. Eventually, advances in imaging methods during the 1980s and 1990s, particularly ultrasound imaging and MRI, helped further advance thermal applications for treating tumours $(15,51,158,159)$.

The first clinical HIFU devices proposed in the 1990s used ultrasound imaging for guidance
$(55,158,160)$. At the same time, more sophisticated techniques for HIFU guidance using MRI were proposed (161). The advantage of ultrasound imaging over MRI is the costs associated with both equipment and infrastructure, as MR requires shielded rooms. However, MRI is the only FDAapproved method for HIFU monitoring because real time temperature measurements are made during the ultrasound exposure (161-163). MR thermometry is particularly well-suited for HIFU providing the ability for closed-loop control of energy deposition, temperature measurement accuracy within $1{ }^{\circ} \mathrm{C}$, spatial resolution of $1 \mathrm{~mm}$, and temporal resolution of $1 \mathrm{sec}$ or less. As a result, the thermal dose of the treatment can be controlled and superposed to anatomical information (164). Additionally, MRI is the only modality that can provide immediate post-treatment assessment of the necrotic area by using standard contrast agent imaging $(29,161)$.

Multiple clinical applications of HIFU guided by imaging have been proposed, and some of them are commonly available in clinics worldwide (29). Overall, both ultrasound- and MR-guided HIFU devices have received wide spread acceptance. The choice of imaging guidance technology is not made by the user since it is integrated into the commercial HIFU device. The two devices more widely used for HIFU prostate treatment required ultrasound imaging for guidance, and it is for these devices that most clinical results have been reported $(53,165,166)$. On the other hand, MR-guided HIFU devices have been approved and extensively used for gynecological applications, particularly uterine fibroid ablation (167-170) and pain palliation from bone metastases (171-173).

Clinical outcomes of HIFU treatments are generally satisfactory but have been reported to be related to practitioner experience $(169,174)$. In particular for prostate cancer treatment using ultrasound-guidance, studies have shown that patients treated with HIFU can have post-therapy recurrence $(53,174,175)$ suggested to be the result from off-target ablation sparing cancerous cells which was later confirmed by tissue biopsies following HIFU exposure (174).

Lessons from ultrasound-guided HIFU treatment of prostate cancer clearly show the value of precise tumour targeting and monitoring of the thermal treatment. Progress in ultrasound imaging techniques is still needed to monitor temperature or 
tissue coagulation for ultrasound-guided HIFU devices (176-178). However, temperature control would not completely solve the clinical issues since the cancerous lesions and surrounding tissues are not easily distinguished.

Recent progress in MR or ultrasound molecular imaging could improve HIFU guidance by clearly defining tumour margins and more accurately identifying areas requiring treatment. A variety of these targeted contrast agents that recognize specific tumour biomarkers have been proposed and tested within in vitro and in vivo settings. MRI contrast agents rely on markerspecific affinity proteins conjugated to either gadolinium (Gd) or super paramagnetic iron oxide (SPIO) and could image tumours in animal models (179-182). Ultrasound contrast agents could be used for guidance by coating the microbubble shell with ligands that target specific cellular markers $(19,111)$. Targeted ultrasound microbubbles have been reported to image cancerous cells in vitro and in animal models $(110,183)$. Contributions to the development of new contrast imaging agents by the pharmaceutical and molecular imaging sciences will propel HIFU-based therapy into the world of personalized medicine by improving treatment guidance.

\section{SUMMARY}

Ultrasound-based therapies, particularly high intensity applications, were inspired by efforts to understand the biological effects of ultrasound energy. Initial therapeutic applications relied purely on the thermal properties of ultrasound taking advantage of its minimally invasive nature and localized effects. Ultrasound has since been developed as a tool for drug delivery by sonoporation, the reversible opening of the blood brain barrier, and the release of drugs from protective carriers by localized heat. Other therapeutic applications of ultrasound have been suggested such as the lysis of clots and drug delivery through the skin using sonophoresis. HIFU therapy was advanced by merging clinical devices with medical imaging technology but also with substantial contributions by biotechnology, medicinal chemistry and the pharmaceutical sciences. The pace at which current ultrasound research is progressing coupled with renewed interest in ultrasound therapy has led to significant investment in additional HIFU facilities throughout the world. New HIFU facilities providing access to multi-disciplinary research teams will establish high intensity ultrasound as an emerging clinical tool for advanced drug delivery and therapy.

\section{REFERENCES}

1. Curie P, Curie J. Développement, par pression, de électricité polaire dans les cristaux hémièdres à faces inclinées. Académie des sciences (France) Comptes rendus hebdomadaires des séances de l'Académie des sciences 1880:294-295.

2. Chilowski C, Langevin P, inventors. Production of submarine signals and the location of submarine objects 1923.

3. Suslick KS. Sonochemistry. Science 1990;247 (4949):1439-1445.

4. Suslick KS, Flannigan DJ. Inside a collapsing bubble: sonoluminescence and the conditions during cavitation Annu Rev Phys Chem 2008; 59:659-683.

5. Flannigan DJ, Suslick KS. Plasma formation and temperature measurement during single-bubble cavitation Nature 2005 Mar 3;434(7029):52-55.

6. Skauen DM. Some pharmaceutical applications of ultrasonics J Pharm Sci 1967 Nov;56(11):13731385.

7. Shirsath SR, Sonawane SH, Gogate PR. Intensification of extraction of natural products using ultrasonic irradiations:A review of current status. Chemical Engineering and Processing: Process Intensification 2012 /3;53(0):10-23.

8. Higgins DM, Skauen DM. Influence of power on quality of emulsions prepared by ultrasound $\mathrm{J}$ Pharm Sci 1972 Oct;61(10):1567-1570.

9. Mason TJ. Ultrasound in synthetic organic chemistry. Chem Soc Rev 1997;26(6):443-451.

10. Shah RB, Zidan AS, Funck T, Tawakkul MA, Nguyenpho A, Khan MA. Quality by design: characterization of self-nano-emulsified drug delivery systems (SNEDDs) using ultrasonic resonator technology Int J Pharm 2007 Aug 16;341(1-2):189-194.

11. Xu H, Suslick KS. Sonochemical synthesis of highly fluorescent ag nanoclusters ACS Nano 2010 Jun 22;4(6):3209-3214.

12. Dhas NA, Suslick KS. Sonochemical preparation of hollow nanospheres and hollow nanocrystals J Am Chem Soc 2005 Mar 2;127(8):2368-2369.

13. Skrabalak SE, Suslick KS. Porous MoS2 synthesized by ultrasonic spray pyrolysis J Am Chem Soc 2005 Jul 20;127(28):9990-9991.

14. Hill CR, Bamber JC. Methodology for clinical investigation. Physical Principles of Medical Ultrasonics, Second Edition 2004:255-302. 
15. ter Haar G. Intervention and therapy. Ultrasound Med Biol 2000 May;26 Suppl 1:S51-4.

16. van den Bekerom MP, van der Windt DA, Ter Riet G, van der Heijden GJ, Bouter LM. Therapeutic ultrasound for acute ankle sprains. Cochrane Database Syst Rev 2011 Jun 15;(6):CD001250. doi(6):CD001250.

17. Huber M, Prantl L, Gehmert S. Successful treatment of nonunion in severe finger injury with low-intensity pulsed ultrasound (LIPUS): a case report J Med Case Rep 2012 Jul 18;6(1):209-19476-209.

18. Deshpande N, Needles A, Willmann JK. Molecular ultrasound imaging: current status and future directions. Clin Radiol 2010;65(7):567-581.

19. Bohmer MR, Klibanov AL, Tiemann K, Hall CS, Gruell H, Steinbach OC. Ultrasound triggered image-guided drug delivery Eur J Radiol 2009 May;70(2):242-253.

20. Hynynen K. Macromolecular delivery across the blood-brain barrier Methods Mol Biol 2009; 480:175-185.

21. Harvey EN, Harvey EB, Loomis AL. Further observations on the effect of high frequency sound waves on living matter. Biol Bull 1928;55(6):459469.

22. Lynn JG, Zwemer RL, Chick AJ, Miller AE. A New Method for the Generation and use of Focused Ultrasound in Experimental Biology. J Gen Physiol 1942 Nov 20;26(2):179-193.

23. The use of ultrasound in neurosurgery. Proceedings of the Third International Conference on Medical Electronics; 1960.

24. Goss SA, Frizzell LA, Dunn F. Ultrasonic absorption and attenuation in mammalian tissues Ultrasound Med Biol 1979;5(2):181-186.

25. Lee CS, Frizzell LA. Exposure levels for ultrasonic cavitation in the mouse neonate Ultrasound Med Biol 1988;14(8):735-742.

26. O'Brien WD,Jr. Ultrasound-biophysics mechanisms Prog Biophys Mol Biol 2007 Jan-Apr;93(1-3):212255.

27. O'Brien WD,Jr, Simpson DG, Ho MH, Miller RJ, Frizzell LA, Zachary JF. Superthreshold behavior and threshold estimation of ultrasound-induced lung hemorrhage in pigs: role of age dependency IEEE Trans Ultrason Ferroelectr Freq Control 2003 Feb;50(2):153-169.

28. O'Brien WR, Ellis DS. Evaluation of the unscanned soft-tissue thermal index IEEE Trans Ultrason Ferroelectr Freq Control 1999;46(6):1459-1476.

29. Zhou YF. High intensity focused ultrasound in clinical tumor ablation World J Clin Oncol 2011 Jan 10;2(1):8-27.

30. Pennes HH. Analysis of tissue and arterial blood temperatures in the resting human forearm. 1948. J
Appl Physiol 1998 Jul;85(1):5-34.

31. Sapareto SA, Dewey WC. Thermal dose determination in cancer therapy. Int J Radiat Oncol Biol Phys 1984 Jun;10(6):787-800.

32. Billard BE, Hynynen K, Roemer RB. Effects of physical parameters on high temperature ultrasound hyperthermia. Ultrasound Med Biol 1990;16 (4):409-420.

33. Daum DR, Smith NB, King R, Hynynen K. In vivo demonstration of noninvasive thermal surgery of the liver and kidney using an ultrasonic phased array. Ultrasound Med Biol 1999 Sep;25(7):10871098.

34. Damianou C, Hynynen K. The effect of various physical parameters on the size and shape of necrosed tissue volume during ultrasound surgery J Acoust Soc Am 1994 Mar;95(3):1641-1649.

35. Pichardo S, Sin VW, Hynynen K. Multi-frequency characterization of the speed of sound and attenuation coefficient for longitudinal transmission of freshly excised human skulls Phys Med Biol 2011 Jan 7;56(1):219-250.

36. Pichardo S, Hynynen K. Treatment of near-skull brain tissue with a focused device using shearmode conversion: a numerical study. Phys Med Biol52(24) 2007;52(24):7313-7332.

37. Burtnyk M, N'Djin WA, Kobelevskiy I, Bronskill M, Chopra R. 3D conformal MRI-controlled transurethral ultrasound prostate therapy: validation of numerical simulations and demonstration in tissue-mimicking gel phantoms Phys Med Biol 2010 Nov 21;55(22):6817-6839.

38. Pichardo S, Hynynen K. New design for an endoesophageal sector-based array for the treatment of atrial fibrillation: a parametric simulation study. IEEE Trans Ultrason Ferroelectr Freq Control 2009;56(3):600-612.

39. Engel DJ, Muratore R, Hirata K, Otsuka R, Fujikura K, Sugioka K, et al. Myocardial lesion formation using high-intensity focused ultrasound $\mathrm{J}$ Am Soc Echocardiogr 2006 Jul;19(7):932-937.

40. Pichardo S, Hynynen K. Circumferential lesion formation around the pulmonary veins in the left atrium with focused ultrasound using a 2D-array endoesophageal device: a numerical study. Phys Med Biol 2007 Aug 21;52(16):4923-4942.

41. Leong $\mathrm{T}$, Ashokkumar $\mathrm{M}$, Kentish $\mathrm{S}$. The fundamentals of power ultrasound-a review. Acoustics Australia 2011;39(2-55).

42. Hill C. The Wider Context of Sonography. Physical Principles of Medical Ultrasonics, Second Edition 2004:337-347.

43. Leighton T. The acoustic bubble. : Access Online via Elsevier; 1994.

44. Chavrier F, Chapelon JY, Gelet A, Cathignol D. Modeling of high-intensity focused ultrasound- 
induced lesions in the presence of cavitation bubbles. J Acoust Soc Am 2000 Jul;108(1):432440.

45. Sassaroli E, Hynynen K. Forced linear oscillations of microbubbles in blood capillaries. J Acoust Soc Am 2004;115(6):3235.

46. Sokka S, Gauthier TP, Hynynen K. Theoretical and experimental validation of a dual-frequency excitation method for spatial control of cavitation. Phys Med Biol 2005;50(9):2167-2179.

47. Barnett S, ter Haar G, Ziskin M, Rott H, Duck F, Maeda K. International recommendations and guidelines for the safe use of diagnostic ultrasound in medicine. Ultrasound Med Biol 2000;26(3):355366.

48. Aptel F, Lafon C. Therapeutic applications of ultrasound in ophthalmology Int $\mathrm{J}$ Hyperthermia 2012;28(4):405-418.

49. Fry WJ, Fry FJ. Fundamental Neurological Research and Human Neurosurgery Using Intense Ultrasound. IRE Transactions on Medical Electronics 1960;ME-7:166-181.

50. Coleman DJ, Lizzi FL, Driller J, Rosado AL, Burgess SE, Torpey JH, et al. Therapeutic ultrasound in the treatment of glaucoma. II. Clinical applications. Ophthalmology 1985 Mar;92(3):347-353.

51. Tempany CM, Stewart EA, McDannold N, Quade BJ, Jolesz FA, Hynynen K. MR imaging-guided focused ultrasound surgery of uterine leiomyomas: a feasibility study. Radiology 2003 Mar;226(3):897-905.

52. Chopra R, Baker N, Choy V, Boyes A, Tang K, Bradwell D, et al. MRI-compatible transurethral ultrasound system for the treatment of localized prostate cancer using rotational control. Med Phys 2008 Apr;35(4):1346-1357.

53. Crouzet S, Rebillard X, Chevallier D, Rischmann P, Pasticier G, Garcia G, et al. Multicentric oncologic outcomes of high-intensity focused ultrasound for localized prostate cancer in 803 patients Eur Urol 2010 Oct;58(4):559-566.

54. Gelet A, Chapelon JY, Bouvier R, Rouviere O, Lasne Y, Lyonnet D, et al. Transrectal highintensity focused ultrasound: minimally invasive therapy of localized prostate cancer. J Endourol 2000 Aug;14(6):519-528.

55. Sanghvi NT, Foster RS, Bihrle R, Casey R, Uchida $\mathrm{T}$, Phillips $\mathrm{MH}$, et al. Noninvasive surgery of prostate tissue by high intensity focused ultrasound: an updated report. Eur J Ultrasound 1999 Mar;9(1):19-29.

56. Uchida T, Sanghvi NT, Gardner TA, Koch MO, Ishii D, Minei S, et al. Transrectal high-intensity focused ultrasound for treatment of patients with stage $\mathrm{T} 1 \mathrm{~b}-2 \mathrm{n} 0 \mathrm{~m} 0$ localized prostate cancer: a preliminary report. Urology 2002 Mar;59(3):394-8; discussion 398-9.

57. Huber PE, Jenne JW, Rastert R, Simiantonakis I, Sinn HP, Strittmatter HJ, et al. A new noninvasive approach in breast cancer therapy using magnetic resonance imaging-guided focused ultrasound surgery. Cancer Res 2001 Dec 1;61(23):8441-8447.

58. Furusawa H, Namba K, Thomsen S, Akiyama F, Bendet A, Tanaka C, et al. Magnetic resonanceguided focused ultrasound surgery of breast cancer: reliability and effectiveness J Am Coll Surg 2006 Jul;203(1):54-63.

59. Zimmer JE, Hynynen K, He DS, Marcus F. The feasibility of using ultrasound for cardiac ablation IEEE Trans Biomed Eng 1995 Sep;42(9):891-897.

60. Orgera G, Krokidis M, Monfardini L, Bonomo G, Della Vigna $\mathrm{P}$, Fazio $\mathrm{N}$, et al. High intensity focused ultrasound ablation of pancreatic neuroendocrine tumours: report of two cases Cardiovasc Intervent Radiol 2011 Apr;34(2):419423.

61. Melodelima D, Vincenot J, Chen Y, Dupre A, Rivoire M, Chapelon JY. Thermal ablation by high-intensity-focused ultrasound using a toroidal transducer for the treatment of colorectal liver metastases during an open procedure. Clinical results J Acoust Soc Am 2013 May;133(5):3410.

62. Melodelima D, Salomir R, Chapelon JY, Theillere $\mathrm{Y}$, Moonen C, Cathignol D. Intraluminal high intensity ultrasound treatment in the esophagus under fast MR temperature mapping: in vivo studies. Magn Reson Med 2005 Oct;54(4):975-982.

63. Wright C, Hynynen K, Goertz D. In vitro and in vivo high-intensity focused ultrasound thrombolysis Invest Radiol 2012 Apr;47(4):217225.

64. Vaezy S, Marti R, Mourad P, Crum L. Hemostasis using high intensity focused ultrasound Eur J Ultrasound 1999 Mar;9(1):79-87.

65. Hwang JH, Zhou Y, Warren C, Brayman AA, Crum LA. Targeted venous occlusion using pulsed high-intensity focused ultrasound IEEE Trans Biomed Eng 2010 Jan;57(1):37-40.

66. Pichardo S, Milleret R, Curiel L, Pichot O, Chapelon JY. In vitro experimental study on the treatment of superficial venous insufficiency with high-intensity focused ultrasound Ultrasound Med Biol 2006 Jun;32(6):883-891.

67. Madersbacher S, Pedevilla M, Vingers L, Susani M, Marberger M. Effect of high-intensity focused ultrasound on human prostate cancer in vivo Cancer Res 1995 Aug 1;55(15):3346-3351.

68. Niu L, Wang Z, Zou W, Zhang L, Xiang L, Zhu H, et al. Pathological changes on human breast cancer specimens ablated in vitro with high-intensity focused ultrasound Ultrasound Med Biol 2010 
Sep;36(9):1437-1444.

69. Wu F, Wang ZB, Cao YD, Zhou Q, Zhang Y, Xu $Z L$, et al. Expression of tumor antigens and heatshock protein 70 in breast cancer cells after highintensity focused ultrasound ablation Ann Surg Oncol 2007 Mar;14(3):1237-1242.

70. Wu F, Wang ZB, Lu P, Xu ZL, Chen WZ, Zhu H, et al. Activated anti-tumor immunity in cancer patients after high intensity focused ultrasound ablation. Ultrasound Med Biol 2004 Sep;30 (9):1217-1222.

71. Paparel P, Curiel L, Chesnais S, Ecochard R, Chapelon JY, Gelet A. Synergistic inhibitory effect of high-intensity focused ultrasound combined with chemotherapy on Dunning adenocarcinoma. BJU Int 2005 Apr;95(6):881-885.

72. Gelet A, Chapelon JY, Bouvier R, Rouviere O, Lyonnet D, Dubernard JM. Transrectal high intensity focused ultrasound for the treatment of localized prostate cancer: factors influencing the outcome. Eur Urol 2001 Aug;40(2):124-129.

73. Prat F, Centarti M, Sibille A, Abou el Fadil FA, Henry L, Chapelon JY, et al. Extracorporeal highintensity focused ultrasound for VX2 liver tumors in the rabbit. Hepatology 1995 Mar;21(3):832-836.

74. Kinsey AM, Tyreus PD, Rieke V, Butts K, Nau $\mathrm{WH}$, Sommer G, et al. Interstitial ultrasound applicators with dynamic angular control for thermal ablation of tumors under MR-guidance Conf Proc IEEE Eng Med Biol Soc 2004;4:24962499.

75. Chaussy C, Thuroff S, Rebillard X, Gelet A. Technology insight: High-intensity focused ultrasound for urologic cancers. Nat Clin Pract Urol 2005 Apr;2(4):191-198.

76. Gorny KR, Hangiandreou NJ, Hesley GK, Gostout BS, McGee KP, Felmlee JP. MR guided focused ultrasound: technical acceptance measures for a clinical system Phys Med Biol 2006 Jun 21;51(12):3155-3173.

77. Harris GR. FDA regulation of clinical high intensity focused ultrasound (HIFU) devices. 2009 Annual International Conference of the IEEE Engineering in Medicine and Biology Society 2009:145-148.

78. Mitragotri S. Healing sound: the use of ultrasound in drug delivery and other therapeutic applications. Nat Rev Drug Discov 2005 Mar;4(3):255-260.

79. Escobar-Chavez JJ, Bonilla-Martinez D, VillegasGonzalez MA, Rodriguez-Cruz IM, DominguezDelgado CL. The use of sonophoresis in the administration of drugs throughout the skin. J Pharm Pharm Sci 2009;12(1):88-115.

80. Tezel A, Mitragotri S. Interactions of Inertial Cavitation Bubbles with Stratum Corneum Lipid Bilayers during Low-Frequency Sonophoresis.
Biophys J 2003;85(6):3502-3512.

81. Ferrara K, Pollard R, Borden M. Ultrasound microbubble contrast agents: fundamentals and application to gene and drug delivery Annu Rev Biomed Eng 2007;9:415-447.

82. Zhou Y, Cui J, Deng CX. Dynamics of sonoporation correlated with acoustic cavitation activities. Biophys J 2008 Apr 1;94(7):L51-3.

83. Zhou Y, Kumon RE, Cui J, Deng CX. The size of sonoporation pores on the cell membrane. Ultrasound Med Biol 2009 Oct;35(10):1756-1760.

84. Meijering BD, Juffermans LJ, van Wamel A, Henning RH, Zuhorn IS, Emmer $\mathrm{M}$, et al. Ultrasound and microbubble-targeted delivery of macromolecules is regulated by induction of endocytosis and pore formation Circ Res 2009 Mar 13;104(5):679-687.

85. Kedar RP, Cosgrove D, McCready VR, Bamber JC, Carter ER. Microbubble contrast agent for color Doppler US: effect on breast masses. Work in progress Radiology 1996 Mar;198(3):679-686.

86. Ries F, Honisch C, Lambertz M, Schlief R. A transpulmonary contrast medium enhances the transcranial Doppler signal in humans Stroke 1993 Dec;24(12):1903-1909.

87. Wu J, Pepe J, Rincon M. Sonoporation, anti-cancer drug and antibody delivery using ultrasound Ultrasonics 2006 Dec 22;44 Suppl 1:e21-5.

88. Mehier-Humbert S, Bettinger T, Yan F, Guy RH. Plasma membrane poration induced by ultrasound exposure: implication for drug delivery $\mathrm{J}$ Control Release 2005 May 5;104(1):213-222.

89. Kinoshita M, Hynynen K. A novel method for the intracellular delivery of siRNA using microbubbleenhanced focused ultrasound Biochem Biophys Res Commun 2005 Sep 23;335(2):393-399.

90. Kinoshita M, Hynynen K. Key factors that affect sonoporation efficiency in in vitro settings: the importance of standing wave in sonoporation. Biochem Biophys Res Commun 2007 Aug 10;359(4):860-865.

91. Kinoshita M, Hynynen K. Intracellular delivery of Bak BH3 peptide by microbubble-enhanced ultrasound Pharm Res 2005 May;22(5):716-720.

92. Zhang CB, Cao HL, Li Q, Tu J, Guo X, Liu Z, et al. Enhancement effect of ultrasound-induced microbubble cavitation on branched polyethylenimine-mediated $\operatorname{VEGF(165)}$ transfection with varied N/P ratio Ultrasound Med Biol 2013 Jan;39(1):161-171.

93. Bao S, Thrall BD, Miller DL. Transfection of a reporter plasmid into cultured cells by sonoporation in vitro Ultrasound Med Biol 1997;23(6):953-959.

94. Qiu Y, Zhang C, Tu J, Zhang D. Microbubbleinduced sonoporation involved in ultrasoundmediated DNA transfection in vitro at low acoustic 
pressures J Biomech 2012 May 11;45(8):13391345.

95. Pichardo S, Togtema M, Jackson R, Zehbe I, Curiel L. Influence of cell line and cell cycle phase on sonoporation transfection efficiency in cervical carcinoma cells under the same physical conditions IEEE Trans Ultrason Ferroelectr Freq Control 2013 Feb;60(2):432-435.

96. Togtema M, Pichardo S, Jackson R, Lambert PF, Curiel L, Zehbe I. Sonoporation delivery of monoclonal antibodies against human papillomavirus 16 E6 restores p53 expression in transformed cervical keratinocytes PLoS One 2012;7(11):e50730.

97. Ibsen S, Schutt CE, Esener S. Microbubblemediated ultrasound therapy: a review of its potential in cancer treatment Drug Des Devel Ther 2013 May 3;7:375-388.

98. Sakakima Y, Hayashi S, Yagi Y, Hayakawa A, Tachibana K, Nakao A. Gene therapy for hepatocellular carcinoma using sonoporation enhanced by contrast agents. Cancer Gene Ther 2005;12(11):884-889.

99. Bekeredjian R, Chen S, Grayburn PA, Shohet RV. Augmentation of cardiac protein delivery using ultrasound targeted microbubble destruction Ultrasound Med Biol 2005 May;31(5):687-691.

100. Tsunoda S, Mazda O, Oda Y, Iida Y, Akabame S, Kishida $\mathrm{T}$, et al. Sonoporation using microbubble BR14 promotes pDNA/siRNA transduction to murine heart. Biochem Biophys Res Commun 2005;336(1):118-127.

101. Liang HD. Sonoporation, drug delivery, and gene therapy. Proceedings of the Institution of Mechanical Engineers Part $H$ Journal of Engineering in Medicine 2009;224(2):343.

102. Harrison, G H Harrison, E K Balcer Kubiczek,H A Eddy. Potentiation of Chemotherapy by Low-level Ultrasound. Int J Radiat Biol 1991;59(6):14531466.

103. Larkin JO, Casey GD, Tangney M, Cashman J, Collins CG, Soden DM, et al. Effective tumor treatment using optimized ultrasound-mediated delivery of bleomycin Ultrasound Med Biol 2008 Mar;34(3):406-413.

104. Feril LB,Jr, Kondo T, Takaya K, Riesz P. Enhanced ultrasound-induced apoptosis and cell lysis by a hypotonic medium Int J Radiat Biol 2004 Feb;80(2):165-175.

105. Ashush H, Rozenszajn LA, Blass M, Barda-Saad M, Azimov D, Radnay J, et al. Apoptosis induction of human myeloid leukemic cells by ultrasound exposure Cancer Res 2000 Feb 15;60(4):10141020.

106. Zhang Z, Chen J, Chen L, Yang X, Zhong H, Qi X, et al. Low frequency and intensity ultrasound induces apoptosis of brain glioma in rats mediated by caspase-3, Bcl-2, and survivin Brain Res 2012 Sep 14;1473:25-34.

107. Ferrante EA, Pickard JE, Rychak J, Klibanov A, Ley K. Dual targeting improves microbubble contrast agent adhesion to VCAM-1 and P-selectin under flow J Control Release 2009 Dec 3;140(2):100-107.

108. Guenther F, von zur Muhlen C, Ferrante EA, Grundmann S, Bode C, Klibanov AL. An ultrasound contrast agent targeted to P-selectin detects activated platelets at supra-arterial shear flow conditions Invest Radiol 2010 Oct;45(10):586-591.

109. Pochon S, Tardy I, Bussat P, Bettinger T, Brochot J, von Wronski M, et al. BR55: a lipopeptide-based VEGFR2-targeted ultrasound contrast agent for molecular imaging of angiogenesis. Invest Radiol 2010;45(2):89-95.

110. Wang L, Li L, Guo Y, Tong H, Fan X, Ding J, et al. Construction and in vitro/in vivo targeting of PSMA-targeted nanoscale microbubbles in prostate cancer Prostate 2013 Mar 26.

111. Klibanov AL, Hughes MS, Villanueva FS, Jankowski RJ, Wagner WR, Wojdyla JK, et al. Targeting and ultrasound imaging of microbubblebased contrast agents MAGMA 1999 Aug;8(3):177-184

112. Karshafian R, Samac S, Bevan PD, Burns PN. Microbubble mediated sonoporation of cells in suspension: clonogenic viability and influence of molecular size on uptake Ultrasonics 2010 Jun;50(7):691-697.

113. Karshafian R, Bevan PD, Williams R, Samac S, Burns PN. Sonoporation by ultrasound-activated microbubble contrast agents: effect of acoustic exposure parameters on cell membrane permeability and cell viability Ultrasound Med Biol 2009 May;35(5):847-860.

114. Yudina A, Lepetit-Coiffe M, Moonen CT. Evaluation of the temporal window for drug delivery following ultrasound-mediated membrane permeability enhancement Mol Imaging Biol 2011 Apr;13(2):239-249.

115. Treat LH, McDannold N, Vykhodtseva N, Zhang Y, Tam K, Hynynen K. Targeted delivery of doxorubicin to the rat brain at therapeutic levels using MRI-guided focused ultrasound Int J Cancer 2007 Aug 15;121(4):901-907.

116. Hynynen K. Ultrasound for drug and gene delivery to the brain. Adv Drug Deliv Rev 2008 Jun 30;60(10):1209-1217.

117. Hynynen K, McDannold N, Vykhodtseva N, Jolesz FA. Noninvasive MR imaging-guided focal opening of the blood-brain barrier in rabbits. Radiology 2001 Sep;220(3):640-646. 
118. Sheikov N, McDannold N, Vykhodtseva N, Jolesz F, Hynynen K. Cellular mechanisms of the bloodbrain barrier opening induced by ultrasound in presence of microbubbles. Ultrasound Med Biol 2004;30(7):979-989.

119. Meairs S, Alonso A. Ultrasound, microbubbles and the blood-brain barrier Prog Biophys Mol Biol 2007 Jan-Apr;93(1-3):354-362.

120. Hynynen K, McDannold N, Sheikov N, Jolesz F, Vykhodtseva N. Local and reversible blood-brain barrier disruption by noninvasive focused ultrasound at frequencies suitable for transskull sonications. Neuroimage 2005;24(1):12-20.

121. McDannold N, Vykhodtseva N, Hynynen K. Blood-Brain Barrier Disruption Induced by Focused Ultrasound and Circulating Preformed Microbubbles Appears to Be Characterized by the Mechanical Index. Ultrasound Med Biol 2008;34(5):834-840.

122. Kinoshita M, McDannold N, Jolesz FA, Hynynen $\mathrm{K}$. Targeted delivery of antibodies through the blood-brain barrier by MRI-guided focused ultrasound. Biochem Biophys Res Commun 2006 Feb 24;340(4):1085-1090.

123. Marquet F, Tung YS, Teichert T, Ferrera VP, Konofagou EE. Noninvasive, transient and selective blood-brain barrier opening in non-human primates in vivo. PLoS One 2011;6(7):e22598.

124. Aryal M, Vykhodtseva N, Zhang YZ, Park J, McDannold N. Multiple treatments with liposomal doxorubicin and ultrasound-induced disruption of blood-tumor and blood-brain barriers improve outcomes in a rat glioma model. J Control Release 2013 Jul 10;169(1-2):103-111.

125. Park EJ, Zhang YZ, Vykhodtseva N, McDannold $\mathrm{N}$. Ultrasound-mediated blood-brain/blood-tumor barrier disruption improves outcomes with trastuzumab in a breast cancer brain metastasis model. J Control Release 2012 Nov 10;163(3):277284.

126. Jordão J, Ayala-Grosso C, Markham K, Huang Y, Chopra R, McLaurin J, et al. Antibodies Targeted to the Brain with Image-Guided Focused Ultrasound Reduces Amyloid-b Plaque Load in the TgCRND8 Mouse Model of Alzheimer's Disease. PLoS ONE 2010;5(5):e10549.

127. Alonso A, Reinz E, Leuchs B, Kleinschmidt J, Fatar M, Geers B, et al. Focal Delivery of AAV2/1transgenes Into the Rat Brain by Localized Ultrasound-induced BBB Opening. Mol Ther Nucleic Acids 2013 Feb 19;2:e73.

128. Porter TR,. The utilization of ultrasound and microbubbles for therapy in acute coronary syndromes. Cardiovasc Res 2009;83(4):636-642.

129. Akiyama M, Ishibashi T, Yamada T, Furuhata $H$. Low-frequency ultrasound penetrates the cranium and enhances thrombolysis in vitro. Neurosurgery 1998 Oct;43(4):828-32; discussion 832-3.

130. Bor-Seng-Shu E, Nogueira Rde C, Figueiredo EG, Evaristo EF, Conforto AB, Teixeira MJ. Sonothrombolysis for acute ischemic stroke: a systematic review of randomized controlled trials Neurosurg Focus 2012 Jan;32(1):E5.

131. Tsivgoulis G, Alexandrov AV. Ultrasound enhanced thrombolysis: applications in acute cerebral ischemia J Clin Neurol 2007 Mar;3(1):1-8.

132. Alexandrov AV, Molina CA, Grotta JC, Garami Z, Ford SR, Alvarez-Sabin J, et al. Ultrasoundenhanced systemic thrombolysis for acute ischemic stroke. N Engl J Med 2004 Nov 18;351(21):21702178.

133. Califf RM, Fortin DF, Tenaglia AN, Sane DC. Clinical risks of thrombolytic therapy. Am J Cardiol 1992 Jan 3;69(2):12A-20A.

134. Susman E. News from the International Stroke Conference: Hands-free Headband Device Improves Clotbuster Efficacy. Neurology today 2012;12(6):24.

135. Maxwell A, Cain C, Duryea A, Yuan L, Gurm H, $\mathrm{Xu}$ Z. Noninvasive thrombolysis using pulsed ultrasound cavitation therapy - Histotrispy. Ultrasound Med Biol 2009;35(12):1982-1994.

136. Marsh JN, Senpan A, Hu G, Scott MJ, Gaffney PJ, Wickline SA, et al. Fibrin-targeted perfluorocarbon nanoparticles for targeted thrombolysis. Nanomedicine 2007;2(4):533-543.

137. McCarthy JR, Sazonova IY, Erdem SS, Hara T, Thompson BD, Patel P, et al. Multifunctional nanoagent for thrombus-targeted fibrinolytic therapy. Nanomedicine (Lond) 2012 Jul;7(7):10171028.

138. Ta T, Porter TM. Thermosensitive liposomes for localized delivery and triggered release of chemotherapy. J Control Release 2013 Jul 10;169(1-2):112-125.

139. Yatvin MB, Weinstein JN, Dennis WH, Blumenthal R. Design of liposomes for enhanced local release of drugs by hyperthermia. Science 1978 Dec 22;202(4374):1290-1293.

140. Hynynen K, Lulu BA. Hyperthermia in cancer treatment. Invest Radiol 1990 Jul;25(7):824-834.

141. Kong G, Anyarambhatla G, Petros WP, Braun RD, Colvin OM, Needham D, et al. Efficacy of liposomes and hyperthermia in a human tumor xenograft model: importance of triggered drug release. Cancer Res 2000 Dec 15;60(24):69506957.

142. Needham D, Anyarambhatla G, Kong G, Dewhirst MW. A new temperature-sensitive liposome for use with mild hyperthermia: characterization and testing in a human tumor xenograft model. Cancer Res 2000 Mar 1;60(5):1197-1201. 
143. Huang SK, Stauffer PR, Hong K, Guo JW, Phillips TL, Huang A, et al. Liposomes and hyperthermia in mice: increased tumor uptake and therapeutic efficacy of doxorubicin in sterically stabilized liposomes. Cancer Res 1994 Apr 15;54(8):21862191.

144. Manzoor AA, Lindner LH, Landon CD, Park JY, Simnick AJ, Dreher MR, et al. Overcoming limitations in nanoparticle drug delivery: triggered, intravascular release to improve drug penetration into tumors. Cancer Res 2012 Nov 1;72(21):55665575.

145. Staruch R, Chopra R, Hynynen K. Localised drug release using MRI-controlled focused ultrasound hyperthermia. Int J Hyperthermia 2011;27(2):156171.

146. Staruch R, Chopra R, Hynynen K. Hyperthermia in bone generated with MR imaging-controlled focused ultrasound: control strategies and drug delivery. Radiology 2012 Apr;263(1):117-127.

147. Ranjan A, Jacobs GC, Woods DL, Negussie AH, Partanen A, Yarmolenko PS, et al. Image-guided drug delivery with magnetic resonance guided high intensity focused ultrasound and temperature sensitive liposomes in a rabbit Vx2 tumor model. J Control Release 2012 Mar 28;158(3):487-494.

148. de Smet M, Langereis S, van den Bosch S, Grull H. Temperature-sensitive liposomes for doxorubicin delivery under MRI guidance. J Control Release 2010 Apr 2;143(1):120-127.

149. Negussie AH, Yarmolenko PS, Partanen A, Ranjan A, Jacobs G, Woods D, et al. Formulation and characterisation of magnetic resonance imageable thermally sensitive liposomes for use with magnetic resonance-guided high intensity focused ultrasound. Int J Hyperthermia 2011;27(2):140155.

150. de Smet M, Heijman E, Langereis S, Hijnen NM, Grull H. Magnetic resonance imaging of high intensity focused ultrasound mediated drug delivery from temperature-sensitive liposomes: an in vivo proof-of-concept study. J Control Release 2011 Feb 28;150(1):102-110.

151. de Smet M, Langereis S, van den Bosch S, Bitter K, Hijnen NM, Heijman E, et al. SPECT/CT imaging of temperature-sensitive liposomes for MR-image guided drug delivery with high intensity focused ultrasound. J Control Release 2013 Jul 10;169(1-2):82-90.

152. Gasselhuber A, Dreher MR, Partanen A, Yarmolenko PS, Woods D, Wood BJ, et al. Targeted drug delivery by high intensity focused ultrasound mediated hyperthermia combined with temperature-sensitive liposomes: computational modelling and preliminary in vivovalidation. Int $\mathrm{J}$ Hyperthermia 2012;28(4):337-348.
153. Oerlemans C, Deckers R, Storm G, Hennink WE, Nijsen JF. Evidence for a new mechanism behind HIFU-triggered release from liposomes. J Control Release 2013 Jun 28;168(3):327-333.

154. Li L, ten Hagen TL, Hossann M, Suss R, van Rhoon GC, Eggermont AM, et al. Mild hyperthermia triggered doxorubicin release from optimized stealth thermosensitive liposomes improves intratumoral drug delivery and efficacy. J Control Release 2013 Jun 10;168(2):142-150.

155. Park SM, Kim MS, Park SJ, Park ES, Choi KS, Kim YS, et al. Novel temperature-triggered liposome with high stability: formulation, in vitro evaluation, and in vivo study combined with highintensity focused ultrasound (HIFU). J Control Release 2013 Sep 28;170(3):373-379.

156. Deckers R, Paradissis A, Oerlemans C, Talelli M, Storm G, Hennink WE, et al. New insights into the HIFU-triggered release from polymeric micelles. Langmuir 2013 Jul 30;29(30):9483-9490.

157. Gong J, Chen M, Zheng Y, Wang S, Wang Y. Polymeric micelles drug delivery system in oncology. J Control Release 2012 May 10;159(3):312-323.

158. Chapelon JY, Ribault M, Vernier F, Souchon R, Gelet A. Treatment of localised prostate cancer with transrectal high intensity focused ultrasound. Eur J Ultrasound 1999 Mar;9(1):31-38.

159. Yagel S. High-intensity focused ultrasound: a revolution in non-invasive ultrasound treatment? Ultrasound Obstet Gynecol 2004 Mar;23(3):216217.

160. Chapelon JY, Margonari J, Bouvier R, Cathignol D, Gorry F, Gelet A. Tissue ablation by focused ultrasound Prog Urol 1991 Apr;1(2):231-243.

161. Hynynen K, Darkazanli A, Unger E, Schenck JF. MRI-guided noninvasive ultrasound surgery. Med Phys 1993 Jan-Feb;20(1):107-115.

162. Chung AH, Jolesz FA, Hynynen K. Thermal dosimetry of a focused ultrasound beam in vivo by magnetic resonance imaging. Med Phys 1999 Sep;26(9):2017-2026.

163.Quesson B, de Zwart JA, Moonen CT. Magnetic resonance temperature imaging for guidance of thermotherapy. J Magn Reson Imaging 2000 Oct;12(4):525-533.

164. McDannold NJ, King RL, Jolesz FA, Hynynen KH. Usefulness of MR imaging-derived thermometry and dosimetry in determining the threshold for tissue damage induced by thermal surgery in rabbits. Radiology 2000 Aug;216(2):517-523.

165. Blana A, Rogenhofer S, Ganzer R, Lunz JC, Schostak M, Wieland WF, et al. Eight Years' Experience With High-Intensity Focused Ultrasonography for Treatment of Localized Prostate Cancer. Urology 2008 Sep 29;72(6):1329- 
1333.

166. Uchida T, Ohkusa H, Yamashita H, Shoji S, Nagata $\mathrm{Y}$, Hyodo $\mathrm{T}$, et al. Five years experience of transrectal high-intensity focused ultrasound using the Sonablate device in the treatment of localized prostate cancer Int J Urol 2006 Mar;13(3):228-233.

167. Dorenberg EJ, Courivaud F, Ring E, Hald K, Jakobsen JA, Fosse E, et al. Volumetric ablation of uterine fibroids using Sonalleve high-intensity focused ultrasound in a 3 Tesla scanner - first clinical assessment Minim Invasive Ther Allied Technol 2012 Jul 16.

168. Hesley GK, Gorny KR, Woodrum DA. MR-Guided Focused Ultrasound for the Treatment of Uterine Fibroids Cardiovasc Intervent Radiol 2012 Mar 28.

169. Kim HS, Baik JH, Pham LD, Jacobs MA. MRguided high-intensity focused ultrasound treatment for symptomatic uterine leiomyomata: long-term outcomes Acad Radiol 2011 Aug;18(8):970-976.

170. Rabinovici J, Inbar Y, Revel A, Zalel Y, Gomori JM, Itzchak Y, et al. Clinical improvement and shrinkage of uterine fibroids after thermal ablation by magnetic resonance-guided focused ultrasound surgery Ultrasound Obstet Gynecol 2007 Oct;30(5):771-777.

171. Huisman M, van den Bosch MA. MR-guided highintensity focused ultrasound for noninvasive cancer treatment Cancer Imaging 2011 Oct 3;11:S161-6.

172. Gianfelice D, Gupta C, Kucharczyk W, Bret P, Havill D, Clemons M. Palliative treatment of painful bone metastases with MR imaging--guided focused ultrasound Radiology 2008 Oct;249(1):355-363.

173. Catane R, Beck A, Inbar Y, Rabin T, Shabshin N, Hengst S, et al. MR-guided focused ultrasound surgery (MRgFUS) for the palliation of pain in patients with bone metastases--preliminary clinical experience Ann Oncol 2007 Jan;18(1):163-167.

174. Lawrentschuk N, Finelli A, Van der Kwast TH, Ryan P, Bolton DM, Fleshner NE, et al. Salvage radical prostatectomy following primary high intensity focused ultrasound for treatment of prostate cancer J Urol 2011 Mar;185(3):862-868.

175. Lindner U, Trachtenberg J, Lawrentschuk N. Focal therapy in prostate cancer: modalities, findings and future considerations Nat Rev Urol 2010 Oct;7(10):562-571.

176. Curiel L, Souchon R, Rouviere O, Gelet A, Chapelon JY. Elastography for the follow-up of high-intensity focused ultrasound prostate cancer treatment: initial comparison with MRI. Ultrasound
Med Biol 2005 Nov;31(11):1461-1468.

177. Souchon R, Rouviere O, Gelet A, Detti V, Srinivasan S, Ophir J, et al. Visualisation of HIFU lesions using elastography of the human prostate in vivo: preliminary results. Ultrasound Med Biol 2003 Jul;29(7):1007-1015.

178. Curiel L, Chopra R, Hynynen K. In vivo monitoring of Focused Ultrasound Surgery using Local Harmonic Motion. Ultrasound Med Biol 2009;35(1):65-78.

179. Tan M, Burden-Gulley SM, Li W, Wu X, Lindner D, Brady-Kalnay SM, et al. MR molecular imaging of prostate cancer with a peptide-targeted contrast agent in a mouse orthotopic prostate cancer model Pharm Res 2012 Apr;29(4):953-960.

180. Gohr-Rosenthal S, Schmitt-Willich H, Ebert W, Conrad J. The demonstration of human tumors on nude mice using gadolinium-labelled monoclonal antibodies for magnetic resonance imaging Invest Radiol 1993 Sep;28(9):789-795.

181. Artemov D, Mori N, Okollie B, Bhujwalla ZM. MR molecular imaging of the Her-2/neu receptor in breast cancer cells using targeted iron oxide nanoparticles. Magn Reson Med 2003 Mar;49(3):403-408.

182. Tomanek B, Iqbal U, Blasiak B, Abulrob A, Albaghdadi H, Matyas JR, et al. Evaluation of brain tumor vessels specific contrast agents for glioblastoma imaging. Neuro Oncol 2012 Jan;14(1):53-63.

183. Bachawal SV, Jensen KC, Lutz AM, Gambhir SS, Tranquart F, Tian L, et al. Earlier detection of breast cancer with ultrasound molecular imaging in a transgenic mouse model. Cancer Res 2013 Mar 15;73(6):1689-1698.

184. Li T, Tachibana K, Kuroki M, Kuroki M. Gene Transfer with Echo-enhanced Contrast Agents: Comparison between Albunex, Optison, and Levovist in Mice--Initial Results. Radiology 2003;229(2):423-428.

185. Forbes MM, Steinberg RL, O'Brien WD,Jr. Examination of inertial cavitation of Optison in producing sonoporation of chinese hamster ovary cells Ultrasound Med Biol 2008 Dec;34(12):20092018.

186. Liu F, Zhu J, Huang Y, Guo W, Rui M, Xu Y, et al. Contrast imaging and gene delivery through the combined use of novel cationic liposomal microbubbles and ultrasound in rat carotid arteries. Arch Med Sci 2013 Apr 20;9(2):347-353. 